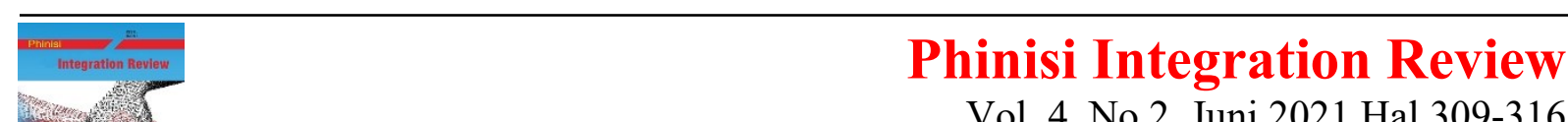

Vol. 4, No.2, Juni 2021 Hal 309-316

Website: http://ojs.unm.ac.id/pir

p-ISSN: 2614-2325 dan e-ISSN: 2614-2317

DOI: https://doi.org/10.26858/pir.v4i2.22098

\title{
Strategi Kepolisian Dalam Penanganan Unjuk Rasa Menyampaikan Pendapat Dimuka Umum Kota Makassar
}

\author{
Nur Ayuni' ${ }^{1}$ Firman Umar' ${ }^{2}$ Muhammad Akbal' \\ ${ }^{123}$ Pendidikan Hukum dan Kewarganegaraan, Universitas Negeri Makassar, Indonesia \\ 1Email: nurayuni071197@gmail.com
}

\begin{abstract}
Abstrak. Penelitian ini bertujuan untuk mengetahui: (1) Bagaimanakah Dinamika Unjuk Rasa Menyampaikan Pendapat Di Muka Umum Kota Makassar; (2) Bagaimanakah Strategi Kepolisian Dalam Menangani Unjuk Rasa Menyampaikan Pendapat Di Muka Umum Kota Makassar; (3) Faktor-Faktor Apa yang Diterminan Dalam menangani Unjuk Rasa Menyampaikan Pendapat Di Muka Umum Kota Makassar. Penelitian menggunakan jenis penelitian kualitatif dengan pendekatan deskriptif. Berdasarkan sumbernya, jenis data yang digunakan yaitu data primer dan sekunder. Data primer diperoleh melalui metode wawancara terhadap Anggota Kepolisian Polrestabes dari Unit Sat Sabhara, Unit Sat Intelkam dan Unit Brimob serta dokumentasi. Sedangkan data sekunder yaitu data yang diperoleh dari berbagai literatul seperti buku, undang-undang maupun sumber lain yang berkaitan. Pengolahan dan penyajian data dilakukan secara deskriptif.Hasil Penelitian menunjukkan bahwa: (1) Dinamika Unjuk Rasa dalam menyampaikan pendapat dimuka umum kota makassar, Kegiatan aksi unjuk rasa yang terjadi dikota makassar pada Bulan Januari hingga desember tahun 2019 sifatnya Fluktuasi. (2) Startegi Kepolisian dalam menangani unjuk menyampaikan pendapat di muka umum kota makassar, berpedoman pada Peraturan Kepala Kepolisian nomor 1 tahun 2009 tentang Penggunaan Kekuatan dalam Tindakan kepolisian. (3) Faktor-Faktor apa yang diterminan dalam menangani unjuk rasa menyampaikan pendapat di muka umum kota makassar. Faktor pendukung yaitu: a) Ada kesiapan fisik dan mental dari pihak kepolisian. b) adanya kerja sama yang baik antara pihak kepolisian, c) Ada respon yang cepat dari instansi kegiatan unjuk rasa. Adapun faktor yang menghambat yaitu: a) melakukan izin tidak sesuai persyaratan administrasi b) adanya provokator, c) melakukan permohonan izin secara mendadak, d) kurangnya komunikasi antara pengunjuk rasa dengan anggota kepolisian.
\end{abstract}

Kata Kunci: Kepolisian dan Unjuk Rasa

\begin{abstract}
The study aims to discover: (1) the dynamics of demonstrations in expressing opinions publicly in Makassar City; (2) the Police strategies in handling demonstrations in expressing opinions publicly in Makassar City; and (3) the determinant factors in handling demonstration in expressing opinions publicly in Makassar City. This study uses qualitative research with a descriptive approach. Based on the source, the types of data used are primary and secondary data. The primary data were obtained through interview with members of the Polrestabes Police from the Sat Sabhara Unit, the Sat Intelkam Unit, and the Brimob Unit as well as documentation. While the secondary data were obtained from various literatures such as books, laws, and other related sources. The data process and data presentation were conducted descriptively. The results of the study show that: (1) the dynamics of demonstration in expressing opinions publicly in Makassar City showed by the demonstration activities that occurred in Makassar City from January to
\end{abstract}


December 2019 were fluctuating, (2) the Police's strategies in handling demonstration in expressing opinions publicly in Makassar city is based on the Regulation of the Chief of Police Number 1 of 2009 concerning the Use of Force in Police Actions, and (3) the determinant factors in handling demonstration in expressing opinions publicly in Makassar city are two, namely the supporting and inhibiting factors. The supporting factors are: a) there is physical and mental readiness from the police, b) there is good cooperation between the police, c) there is a quick response from the demonstration activity agency; whereas the inhibiting factors are: a) permitting does not comply with administrative requirements, b) presence of provocateurs, c) making sudden requests for permits, and d) lack of communication between protesters and police officers.

Keywords: Police, Demonstration.

Ini adalah artikel dengan akses terbuka dibawah licenci CC BY-NC-4.0

(https://creativecommons.org/licenses/by-nc/4.0/ ).

\section{PENDAHULUAN}

Sejak dipisahkannya Kepolisian Negara Republik Indonesia (Polri dari angkatan bersenjata Republik Indonesia (ABRI) pada tanggal 1 April 1999, Kepolisian Negara Republik Indonesia telah banyak melakukan perubahan. Tidak hanya melakukan perubahan struktur namun juga perubahan karakter dan perilaku. Perubahan ini merupakan tuntutan demokrasi agar polisi memainkan perannya sesuai dengan tugas pokoknya menurut pasal 13 Undang-Undang No. 2 Tahun 2002 tentang Kepolisian Negara Republik Indonesia Tugas pokok Kepolisian Negara Republik.

Kemudian dalam penjelasannya dinyatakan: "Rumusan tugas pokok tersebut bukan merupakan urutan prioritas ketiga-tiganya sama penting, sedangkan dalam pelaksanaannya tugas pokok mana yang akan dikedepankan sangat tergantung pada situasi masyarakat dan lingkungan yang dihadapi karena pada dasarnya ketiga tugas pokok tersebut dilaksanakan secara simultan. Disamping itu, dalam pelaksanaan tugas ini harus berdasarkan norma hukum, mengindahkan norma agama, kesopanan, dan kesusilaan, serta menjunjung tinggi Hak Asasi Manusia.

Penanganan keamanan dalam hal kebebasan menyampaikan pendapat di muka umum, merupakan salah satu hak asasi manusia yang dijamin dalam pasal 28 Undang-undang Dasar Negara Republik Indonesia Tahun 1945 yang berbunyi "kemerdekaan berserikat dan berkumpul, mengeluarkan pikiran dengan lisan dan tulisan dan sebagainya ditetapkan dengan Undang-Undang”. Kemerdekaan menyampaikan pendapat tersebut sejalan dengan deklarasi universal Hak-hak Asasi Manusia (Pasal 19) bahwa: "setiap orang berhak atas kebebasan mempunyai dan mengeluarkan pendapat, dalam hal ini termasuk kebebasan mempunyai pendapat dengan tidak mendapat gangguan dan untuk mencari, menerima dan menyampaikan keterangan dan pendapat dengan cara apapun juga dan dengan tidak memandang batas-batas".

Demonstrasi atau unjuk rasa adalah hak setiap warga Negara yang dijamin oleh UndangUndang Nomor 9 Tahun 1998 tentang Kemerdekaan Menyampaikan Pendapat di Muka Umum sehingga setiap warga Negara bebas untuk menyampaikan pendapatnya, baik dalam bentuk unjuk rasa, mimbar bebas, pawai maupun rapat umum dimana hal dimaksud merupakan bagian dari kehidupan demokrasi liberal yang mulai berkembang sejak tahun 1998 setelah terjadinya reformasi.

Perwujudan kehendak warga Negara secara bebas dalam menyampaikan pikiran secara lisan dan tulisan dan sebagainya harus tetap dipelihara agar seluruh tatanan sosial dan kelembagaan baik infrastruktur maupun suprastruktur tetap terbebas dari penyimpangan atau pelanggaran hukum yang bertentangan dengan maksud, tujuan dan arah dari proses keterbukaan dalam pembentukan dan penegakan hukum sehingga tidak menciptakan disintegrasi sosial, tetapi justru harus dapat menjamin rasa aman dalam kehidupan masyarakat. Dengan demikian, maka kemerdekaan menyampaikan 
pendapat di muka umum harus dilaksanakan dengan penuh tanggung jawab, sejalan dengan ketentuan peraturan perundang-undangan yang berlaku dan prinsip hukum internasional.

Pada tanggal 24 September 2019 terjadi aksi demonstrasi di Kota Makassar, ada yang berakhir kondusif dan ada yang berakhir anarkis. Demonstrasi pada saat itu merupakan demonstrasi besar-besaran dimana unjuk rasa mempersoalkan mengenai RUU KUHP, UU KPL, dan beberapa undang-undang yang ingin disah oleh DPR. Berdasarkan hasil observasi awal peneliti di Polrestabes kota Makassar pada tanggal 25 agustus 2020 bersama Ibu Sri, peneliti mendapatkan data 387 kasus unjuk rasa yang terjadi pada tahun 2019. Dan 5101 massa unjuk rasa yang terdata sebagai mahasiswa berasal dari berbagai universitas di Makassar antara lain, Universitas Negeri Makassar (UNM), Kampus Universitas Muslim Indonesia (UMI), Kampus Universitas Hasanuddin (UNHAS), Kampus Universitas Muhammadiyah (UNISMUH. Selain melakukan aksinya di depan kampus, para unjuk rasa juga melakukan demonstrasi dengan melakukan titik kumpul di Kantor DPRD di Jalan A.P. Pettarani, dan Kantor DPRD Provinsi Sulawesi Selatan di Jl. Urip Sumoharjo, dan dibawah jembatan Fly Over. Para unjuk rasa mendatangi Kantor DPRD Provinsi Sulawesi Selatan yang berada di Jl. Urip Sumoharjo dengan keinginan menyampaikan aspirasi mereka dan bertemu dengan pihak anggota DPR pada waktu itu, namun kenyataannya kedatangan mereka tersebut tidak di respon dengan baik. Para unjuk rasa mulai anarkis ingin memasuki kantor DPRD akan tetapi ditahan oleh pihak kepolisian yang sedang mengawal para demonstrasi, unjuk rasa mulai anarkis dengan membakar ban, pihak kepolisian telah memberikan peringatan pertama dengan menembakkan gas air mata namun para unjuk rasa tetap keras melakukan aksinya, kemudian terjadi keributan antara unjuk rasa dengan anggota kepolisian, ada beberapa para unjuk rasa menggunakan senjata tajam. Pada saat kejadian tersebut, banyak korban berjatuhan baik dari pihak kepolisian maupun dari pihak unjuk rasa tersebut. Pada pelaksanaan demonstrasi tersebut pihak kepolisian melakukan penangkapan kepada sejumlah tersangka dalam kerusuhan yang terjadi, dan berdasarkan observasi awal yang telah dilakukan oleh peneliti ada sejumlah 6 orang unjuk rasa yang ditahan pada saat itu. Adanya fenomena dari pelaksanaan demonstrasi tersebut menimbulkan pro dan kontra dikalangan masyarakat. Ada yang berpendapat bahwa demo adalah hak dari setiap warga Negara yang dilindungi oleh Undang-undang dan ada juga yang berpendapat bahwa demo anarkis harus ditindak tegas dengan proses hukum.

Peran polri yang sangat kompleks menjadikan polri memiliki wilayah tugas yang sangat luas dan strategis, sehingga profesionalisme tugas kepolisian harus terus dikembangkan dan ditingkatkan. Masyarakat senantiasa menggantungkan keamanan dan kenyamanan hidupnya kepada polisi baik dalam penanganan kriminalitas maupun dalam penanganan gangguan kamtibmas lainnya, sehingga Polri harus betul-betul dekat dengan masyarakat. Keberhasilan penampilan sosok Polisi yang demikian akan melahirkan rasa kecintaan masyarakat kepada Polisi,

Kaitannya dalam pengamanan pelaksanaan demonstrasi atau unjuk rasa, Kepolisian harus mengambil langkah-langkah pengamanan sesuai dengan aturan perundang-undangan yang berlaku dimana apabila terjadi pelaksanaan demonstrasi harus mengacu kepada UndangUndang Nomor 9 Tahun 1998 tentang Kemerdekaan Menyampaikan Pendapat di Muka Umum, serta berpedoman kepada Peraturan Kepala Kepolisian Negara Republik Indonesia Nomor 16 Tahun 2006 tentang Pedoman Pengendalian Massa

Berdasarkan latar belakang tersebut, peneliti ingin mengetahui secara mendalam bagaimana Strategi yang sesungguhnya dari pihak Kepolisian pada saat penanganan demosntrasi dilapangan, karena setelah melihat beberapa fakta yang terjadi dilapangan pada saat terjadi demonstrasi selalu terjadi keributan antara pihak unjuk rasa dan anggota kepolisian, apakah tugas dan fungsi pihak kepolisian sudah dlaksanakan sesuai yang dicantumkan dalam UndangUndang No. 2 Tahun 2002 tentang Kepolisian Negara Republik Indonesia. Maka dari itu peneliti mengangkat sebuah judul yaitu "Strategi Kepolisian Dalam Penanganan Unjuk Rasa Menyampaikan Pendapat di Muka Umum Kota Makassar"

\section{TINJAUAN PUSTAKA}

\section{A. Definisi Strategi}

Menurut Chainur (1998: 34) konsep strategi dapat didefinisikan berdasarkan dua perspektif yang berbeda, yaitu (1) dari perspektif 
apa yang organisasi lakukan (intends to do), dan (2) dari perspektif apa yang organisasi lakukannya (eventually does)

Sedangkan Arif Gosita (1995: 67) mengatakan bahwa strategi adalah pola keputusan dalam organisasi yang menentukan dan mengungkapkan sasaran, maksud atau tujuan yang menghasilkan kebijakan utama dan merencanakan untuk pencapaian tujuan serta merincu jangkauan yang akan dicapai.

Pengertian diatas mengarahkan kita pada pemahaman bahwa strategi mempunyai suatu pola, metode, maksud / tujuan dan kebijakan serta rencana yang penting. Hal ini diperlukan dalam rangka untuk mencapai suatu tujuan yang di inginkan dan diharapkan.

\section{A. Pengertian Kepolisian Negara Republik Indonesia. \\ 1. Pengertian Kepolisian}

Dalam Kamus Besar Bahasa Indonesia, polisi mempunyai arti yaitu:

a. Badan pemerintah (sekelompok pegawai negeri) yang bertugas memelihara keamanan dan ketertiban umum.

b. Pegawai negeri yang bertugas menjaga keamanan dan ketertiban umum. Dalam pengertian ini istilah Polisi mengandung 2 (dua) pengertian makna Polisi sebagai tugas dan sebagai organnya.

Dalam pasal 1 ayat (1) Undang-undang nomor 2 Tahun 2002 tentang Kepolisian Negara Republik Indonesia menyatakan bahwa "Kepolisian adalah segala hal-ihwal yang berkaitan dengan fungsi dan lembaga Polisi sesuai dengan peraturan perundang-undangan. Sedangkan dalam pasal 5 ayat (1) UndangUndang Nomor 2 Tahun 2002 tentang Kepolisian Negara Republik Indonesia, yaitu: "Kepolisian Negara Republik Indonesia merupakan alat Negara yang berperan dalam memelihara keamanan dan ketertiban masyarakat, menegakkan hukum, serta memberikan perlindungan, pengayoman, dan pelayanan kepada masyarakat dalam rangka terpeliharanya keamanan dalam negeri”

\section{Tugas dan Fungsi Kepolisian}

Menurut Bacharuddin Jusuf Habibie (Habibie, 2006:325) tugas Polisi yaitu menegakkan hukum, siapa yang melanggar rambu-rambu dalam hal ini UUD 1945, MPR, UU, Peraturan Pemerintah atau peraturan daerah, akan menghadapi Polri
Dalam pasal 13 Undang-undang No 2 Tahun 2002, Tugas Pokok Polri adalah sebagai berikut:

1. Memelihara keamanan dan ketertiban masyarakat

2. Menegakkan hukum

3. Memberikan perlindungan, pengayom dan pelayanan kepada masyarakat.

Menurut C.H. MiewHuis untuk melaksanakan tugas pokok, polisi memiliki 2 (dua) fungsi utama yaitu (M. Faal 1991:41):

1. Fungsi Preventif untuk pencegahan, yang berarti bahwa polisi itu berkewajiban melindungi Negara beserta lembagalembaganya, ketertiban dan ketatanan umum, orang-orang dan harta bendanya, dengan jelas mencegah dilakukannya perbuatan-perbuatan yang dapat dihukum dan perbuatan-perbuatan lainnya yang pada hakikatnya dapat mengancam dan membahayakan ketertiban dan ketenteraman umum.

2. Fungsi represif atau pengendalian, yang berarti bahwa polisi itu berkewajiban menyidik perkara-perkara tindak pidana, menangkapi pelaku-pelakunya dan menyerahkannya kepada penyidikan (yustisi) untuk penghukuman.

\section{B. KEMERDEKAAN MENYAMPAIKAN PENDAPAT DIMUKA UMUM}

Menurut Undang-undang Nomor 9 Tahun 1998 tentang Kemerdekaan Menyampaikan Pendapat di Muka Umum, pasal 1 ayat 1 menjelaskan bahwa: Kemerdekaan menyampaikan pendapat dimuka umum adalah hak setiap warga Negara untuk menyampaikan pikiran dengan lisan, tulisan dan sebagainya secara bebas dan bertanggung jawab sesuai dengan ketentuan peraturan perundangundangan yang berlaku.

Adapun jenis penyampaian pendapat di muka umum tercantum dalam pasal (1) ayat 4,5, dan 6 Undang-undang Nomor 9 Tahun 1998 tentang Kemerdekaan Menyampaikan Pendapat di Muka Umum.

Berdasarkan pasal 3 Undang-Undang Nomor 9 Tahun 1998 terdapat lima asas yang merupakan landasan kebebasan bertanggung jawab dan bertindak untuk menyampaikan pendapat di muka umum. Kelima asas tersebut, yaitu:

1. Asas keseimbangan antara hak dan kewajiban

2. Asas musyawarah dan mufakat

3. Asas kepastian hukum dan keadilan 


\section{METODE}

Dalam penelitian ini, peneliti menggunakan metode penelitian kualitatif yang dimana peneliti akan memberikan gambaran dan mendiskripsikan tentang Strategi Kepolisian dalam penanganan Unjuk Rasa tentang kemerdekaan menyampaikan pendapat Kota Makassar

Penelitian ini berlokasi di Polrestabes Makassar tepatnya di Jalan Ahmad Yani No.9, Pattunuang, Kec. Wajo, Kota Makassar, Selawesi Selatan.

Pendekatan yang digunakan dalam penelitian ini adalah pendekatan secara deskriptif kualitatif.

Adapun sumber data dan informan dalam peneitiam ini adalah: Sumber data primer dan Sumber data sekunder

1. Fokus Penelitian.

Dalam proposal penelitian ini, yang menjadi fokus penelitian yaitu Penanganan unjuk rasa dalam menyampaikan pendapat di muka umum oleh Kepolisian Polrestabes di Kota Makassar, unjuk rasa yang dimaksud yaitu unjuk rasa yang terjadi pada tahun 2019.

2. Deskripsi Fokus

a. Dinamika adalah sebuah perubahan pergerakan yang terjadi pada saat unjuk rasa menyampaikan pendapat di muka umum, dalam artian bagaimana isu yang terjadi pada saat unjuk rasa, bagaimana pola penanganan pada saat unjuk rasa, kemudian aturan bukumnya untuk melakukan unjuk rasa

b. Strategi adalah Tindakan yang dilakukan oleh kepolisian untuk menangani unjuk rasa, seperti peraturan seperti apa yang digunakan, kemudian alat-alat yang digunakan oleh kepolisian untuk penangnan unjuk rasa dilapangan.

c. Faktor diterminan adalah Beberapa hal yang menjadi pendukung dan penghambat pada saat proses penanganan unjuk rasa.

Dengan menggunakan instrument wawancara, buku catatan dan alat tulis, kamera dan rekaman suara. Dengan Teknik pengumpulan data Wawancara dan Dokumentasi. Kemudian Teknik Pengecekan Keabsahan Datamenggunakan Triangulasi (peer debriefing) dan Member Chek. Teknik Analisis Data yaitu: Redukasi data, Penyajian data, Pengambilan kesimpulan atau verifikasi

\section{HASIL DAN PEMBAHASAN}

Setelah dilaksanakan penelitian dilapangan , maka dapat diuraikan temuan data dilapangan terkait Strategi Kepolisian Dalam Penanganan Unjuk Rasa Menyampaikan Pendapat Di Muka Umum Kota Makassar.

1. Dinamika unjuk rasa dalam menyampaikan pendapat dimuka umum dikota makassar.

Kegiatan unjuk rasa yang terjadi pada bulan januari hingga desember tahun 2019 sifatnya Fluktuasi artinya Kasus unjuk rasa yang terjadi mengalami kenaikan dan penurunan yang tidak menentu setiap bulannya dan dari berbagai isu yang berbeda-beda.

2. Strategi Kepolisian dalam Penanganan Unjuk Rasa Dalam Menyampaikan Pendapat Di Muka Umum Kota Makassar.

Berpedoman kepada Peraturan Kepala Kepolisian nomor 1 tahun 2009 tentang Penggunaan Kekuatan dalam Tindakan kepolisian tepatnya dalam pasal 5 ayat 1 yaitu:

Tahap 1: kekuatan yang memiliki dampak deterrent/pencegahan;

TahaP 2 : Perintah lisan

Tahap 3 : Kendali tangan kosong lunak

Tahap 4 : Kendali tangan kosong keras

Tahap 5: kendali senjata tumpul, senjata kimia antara lain gas air mata, semprotan cabe atau alat lain sesuai standar Polri.

Tahap 6: kendali dengan menggunakan senjata api atau alat lain yang menghentikan tindakan atau perilaku pelaku kejahatan atau tersangka yang dapat menyebabkan luka parah atau kematian anggota Polri atau anggota masyarakat.

3 Faktor-Faktor Apa Yang Diterminan Dalam Menangani Unjuk Rasa Menyampaikan Pendapat di Muka Umum di Kota Makassar.

Faktor yang determinan dalam penanganan unjuk rasa dalam menyampaikan pendapat di muka umum kota makassar ada dua faktor yaitu faktor pendukung dan faktor penghambat.

Faktor pendukung yaitu:

a) Ada kesiapan fisik dan mental dari pihak kepolisian.

b) adanya kerja sama yang baik antara pihak kepolisian.

c) Ada respon yang cepat dari instansi kegiatan unjuk rasa.

Adapun faktor yang menghambat yaitu: 
a) melakukan izin tidak sesuai persyaratan administrasi

b) adanya provokator.

c) melakukan permohonan izin secara mendadak.

d) kurangnya komunikasi antara pengunjuk rasa dengan anggota kepolisian.

\section{Pembahasan}

1. Dinamika Unjuk Rasa Dalam Menyampaikan Pendapat di Muka Umum di Kota Makassar.

Unjuk rasa merupakan sebuah kegiatan yang dilakukan oleh seorang atau lebih untuk mengeluarkan pikiran dengan lisan, tulisan dan sebagainya secara demonstrasi di muka umum. Unjuk rasa umumnya dilakukan oleh kelompok mahasiswa dan orang-orang yang tidak setuju dengan pemerintah dan yang menentang kebijakan pemerintah. Namun ada unjuk rasa juga dilakukan oleh kelompok-kelompok lainnya dengan tujuan lainnya. Unjuk rasa kadang dapat menyebabkan perusakan terhadap benda-benda. Hal ini dapat terjadi akibat keinginan menunjukkan pendapat para pengunjuk rasa yang berlebihan.

Dinamika unjuk rasa yang terjadi dikota makassar umumnya dari tahun ke tahun mengalami perubahan, perubahan tersebut selalu berkaitan dengan isu apa yang diangkat pada saat melakukan unjuk rasa. seperti yang di dapatkan dari hasil wawancara pihak kepolisian mengatakan setiap tahun terjadi unjuk rasa sesuai dengan kalender kamtibmas, pola dalam melakukan unjuk rasa pun selalu berubah.

kegiatan unjuk rasa yang dilakukan pengunjuk rasa selalu tidak sesuai aturan dalam menjalankan unjuk rasa yang dimana telah tercantum dalam Undang-undang Nomor 8 tahun 1998 tentang kemerdekaan menyampaikan pendapat di muka umum mengatur tata cara dan pembatasan penyampaian pendapat dimuka umum. Diantara tata caranya adalah kewajiban untuk memberikan surat pemeritahuan kepada polisi selambat-lambatnya $3 \quad$ x $\quad 24$ jam sebelum kegiatan dimulai, mencantumkan siapa penanggung jawabnya, berapa jumlah massa, siapa kordinator lapangan, tempat, waktu dan isu yang akan disampaikan, hal ini dimaksudkan agar pihak Kepolisian dapat menyiapkan pengamanan yang baik, sebagaimana telah tercantum dalam Pasal 10

Ada 2 hal yang dilakukan oleh kepolisian untuk menyelesaikan unjuk rasa dengan baik antara pengunjuk rasa dengan kepolisian sebagai berikut:

1. Negoisasi

2. Komunikasi.

2. Strategi Kepolisian dalam Penanganan Unjuk Rasa Menyampaikan Pendapat di Muka Umum di Kota Makassar.

Dalam ketiga tugas dan wewenang tersebut yang terdapat pada pasal 13 Undangundang Republik Indonesia Nomor 2 tahun 2002 dapat dikaitkan dengan Undang-undang Republik Indonesia Nomor 9 tahun 1998 tentang Kemerdekaan Menyampaikan Pendapat di Muka Umum. Tugas dan wewenang polisi dalam memelihara keamanan dan ketertiban masyarakat pada tugas dan wewenang tersebut dapat dikaitkan dengan pasal 13 ayat (3) Undang-undang Republik Indonesia Nomor 9 tahun 1998 yang menyatakan bahwa "dalam menyampaikan pendapat dimuka umum, polri bertanggung jawab menyelenggarakan pengamanan untuk menjamin keamanan dan ketertiban umum sesuai dengan prosedur yang berlaku. Hal ini telah sesuai dengan tugas polisi sebagai pemelihara keamanan dan ketertiban masyarakat.

Saat terjadinya unjuk rasa ada 3 tahapan dalam pelaksanaan pengamanan unjuk rasa. tahapan ini disesuaikan dengan keadaan atau situasi kegiatan unjuk rasa:

1. Tahapan situasi tertib (Hijau)

Tahapan tertib adalah tahapan dimana kegiatan unjuk rasa masih erjalan aman, tidak ada kegiatan yang mengarah pada kegiatan tidak tertib. Dalam situasi tertib diturunkan pasukan dalmas awal. Dalmas awal adalah satuan dalmas yang tidak dilengkapi dengan perlengkapan khusus kepolisian digerakkan dalam menghadapi kondisi massa masih tertib dan teratur (situasi hijau)

2. Tahapan Situasi Tidak Tertib (Kuning)

Tahapan ini negosiator masih terus melakukan negoisasi dengan kordinator lapangan pengunjuk rasa semaksimal mungkin, meskin keadaan sudah tidak tertib (kuning). Situasi tidak tertib adalah situasi dimana para pengunjuk rasa mulai melakukan perbuatan yang menggangu ketertiban dan keamanan sekitar lokasi unjuk rasa, aksi tetrikal dan aksi sejenisnya yang menyusahkan anggota masyarakat lainnya.

3. Tahapan Melanggar Hukum

Situasi melanggar hukum adalah situasi dimana pada saat kegiatan unjuk rasa telah 
terjadi perbuatan perbuatan yang melanggar hukum oleh para pengunjuk rasa.

Dalam hal penanganan unjuk rasa di dalam undang-undang Nomor 2 tahun 2002 memang secara umum hanya membahasa mengenai tugas kepolisian tetapi dalam penanganan unjuk rasa dari hasil penelitian bahwa kepolisian memiliki aturan khusus yang membahas secara detail mengenai penanganan unjuk rasa dilapangan, yaitu di dalam Peraturan Kepolisian Negara Republik Indonesia Nomor 1 tahun 2009 tentang Penggunaan kekuatan dalam Tindakan Kepolisian. Di dalam perkap tersebut, merupakan sebuah strategi yang digunakan kepolisian dalam menangani unjuk rasa, terdapat pada pasal Pasal 5 ayat

3 Faktor Yang Determinan Dalam Penanganan Unjuk Rasa Menyampaikan Pendapat Di Muka Umum Kota Makassar.

a. Faktor Pendukung.

1) Adanya kerja sama yang baik antara anggota petugas yang ditugaskan melakukan penanganan unjuk rasa dilapangan

2) Adanya kesiapan fisik dan mental yang baik dari pihak kepolisian dalam penanganan unjuk rasa dilapangan.

3) Cuaca yang mendukung, dalam artian jika cuaca tidak baik maka akan lebih memudahkan pihak kepolisian dalam penanganan unjuk rasa, karena akan menjadi penghambat bagi pengunjuk rasa dalam melakukan demonstrasi.

4) Adanya komunikasi yang baik antara pihak kepolisian dengan kordinator lapangan dari pengujuk rasa.

\section{b. Faktor Penghambat}

Faktor penghambat adalah semua jenis yang sifatnya menghambat (menjadikan lambat) atau bahkan menghalangi proses penanganan unjuk rasa dalam menyampaikan pendapat dimuka umum lapangan..

Adapun faktor yang dapat menghambat kepolisian dalam penanganan unjuk rasa dalam menyampaikan pendapat dimuka umum dilapangan adalah sebagai berikut:

1) Pengunjuk rasa tidak memberikan informasi atau pemberitahuan secara tertulis kepada Polri setempat

2) Pengunjuk rasa memberikan surat pemberitahuan secara mendadak.

3) Instansi atau Lembaga yang akan menjadi tempat unjuk rasa yang tidak kooperatif untuk memenuhi permintaan pengunjuk rasa agar menghadirkan pimpinan instansi atau Lembaga tersebut.

4) Kurangnya pemahaman dari pengujuk rasa sebelum turun kelapangan untuk melakukan aksi unjuk rasa, terkadang ada yang hanya ikut-ikut yang disebabkan faktor ekonomi dari setiap individu.

5) Adanya provokator yang masuk ke dalam massa unjuk rasa untuk membuat kericuhan.

\section{SIMPULAN DAN SARAN}

Kesimpulan penelitian adalah: (1) Dinamika unjuk rasa dalam menyampaikan pendapat dimuka umum dikota makassar, kegiatan unjuk rasa yang terjadi pada bulan januari hingga desember tahun 2019 sifatnya Fluktuasi; (2) Startegi Kepolisian dalam penanganan unjuk rasa dalam menyampaikan pendapat di muka umum dikota makassar, berpedoman kepada Peraturan Kepala Kepolisian nomor 1 tahun 2009 tentang Penggunaan Kekuatan dalam Tindakan kepolisian; (3) Faktor yang determinan dalam penanganan unjuk rasa dalam menyampaikan pendapat di muka umum kota makassar ada dua faktor yaitu faktor pendukung dan faktor penghambat. Faktor pendukung yaitu: a) Ada kesiapan fisik dan mental dari pihak kepolisian. b) adanya kerja sama yang baik antara pihak kepolisian, c) Ada respon yang cepat dari instansi kegiatan unjuk rasa. Adapun faktor yang menghambat yaitu: a) melakukan izin tidak sesuai persyaratan administrasi b) adanya provokator, c) melakukan permohonan izin secara mendadak, d) kurangnya komunikasi antara pengunjuk rasa dengan anggota kepolisian.

Adapun saran penelitian adalah: (1) Diharapkan untuk pihak Kepolisian dalam menanganani unjuk rasa bersifat Persuasif, mengontrol emosi agar citra polisi dimata masyarakat tidak dipandang jelek dan pihak Kepolisian diharapkan memperhatikan Hak pengunjuk rasa berdasarkan HAM; (2) Diharapkan bagi pengunjuk rasa pada saat ingin melakukan kegiatan unjuk rasa harus mengikuti aturan yang telah ditetapkan, agar tidak berujung anarkis, melakukan permohonan izin sebelum kegiatan dimulai, tidak melakukan permohonan izin secara mendadak agar kepolisian dapat mempersiapkan diri untuk melakukan penanganan, dan lebih memperhatikan pengguna jalan agar kegiatan unjuk rasa tidak mengganggu masyarakat sekitar, tidak mudah 
diprovokatori oleh seseorang untuk melakukan Tindakan yang anarkis dengan pihak kepolisian.

\section{DAFTAR RUJUKAN}

Abdussalam, 2006. Kemerdekaan Menyampaikan Pendapat di Muka Umum. Jakarta: Restu Agung

Gunawan, Wahyu Hartanto. 2013. Perlindungan Hukum Terhadap Polisi Yang Berrtugas Mengamankan Para Demonstrasi di Tinjau dari Undangundang Nomor 39 tahun 1999 tentang Hak Asasi Manusia. .Jurnal Ilmiah

Undang-undang Republik Indonesia Nomor 9 Tahun 1998 tentang Kemerdekaan Menyampaikan Pendapat di Muka Umum.

Undang-undang Republik Indonesia Nomor 2 Tahun 2002 tentang Kepolisian Negara Republik Indonesia
Mahasiswa Universitas Surabaya, Vol.2, No.2.

Malaka, Tan. 2000. Aksi Massa. Cetakan Pertama Jakarta: Teplok Press.

M.Faal. 1990. Penyaringan Perkara Pidana Oleh Polisi. Jakarta: Pradnya Paramitha. Marwan dan Jimmy. 2009. Kamus Hukum, pertama. Surabaya: Reality Publiser. 